\title{
PENYELESAIAN PELANGGARAN KODE ETIK PROFESI BAGI ANGGOTA KEPOLISIAN YANG MELAKUKAN TINDAK PIDANA SYAMSIAR ARIF Universitas Indonesia Timur
}

\begin{abstract}
The basis for investigating members of the National Police who are suspected of committing criminal offenses is the existence of reports or complaints from the public. The report or complaint is submitted through the Head of the Complaints Service Section for the Professional and Security Sector, and then proposes to the Head of Sub-Division through the Head of the Investigation Unit to call and examine members as witnesses to victims and other witnesses. The Police Investigator in addition to carrying out the duties and functions of the Police also has authority in the investigation and law enforcement of members or persons who commit criminal acts. Apart from the foregoing, investigators must pay attention to and settle as well as possible reports or complaints from the public in accordance with their duties and functions as investigators. Investigations of members of the Indonesian National Police who commit criminal acts are carried out by investigators as stipulated in the criminal procedure applicable to the general court environment, which is confirmed in Article 2 of Government Regulation of the Republic of Indonesia Number 3 of 2003 concerning the Technical Implementation of General Judicial Institutions for members of the Police Force. Republic of Indonesia. The examination of members of the Indonesian National Police is carried out in accordance with the rank, namely according to the provisions of Article 5 of Government Regulation where the examination of members of the Indonesian National Police in the course of an investigation is carried out with regard to rank.
\end{abstract}

Keywords: Code of Ethics, Criminal Acts, Police, Violations.

\begin{abstract}
Abstrak
Dasar penyidikan terhadap Anggota Polri yang disangka melakukan tindak pidana adalah adanya laporan atau pengaduan dari masyarakat. Laporan atau pengaduan tersebut disampaikan melalui Kepala Bagian Pelayanan Pengaduan Bidang Profesi dan Pengamanan, selanjutnya mendisposisikan kepada Kepala Sub Bagian Provos melalui Kepala Unit Penyidik untuk melakukan pemanggilan dan pemeriksaan terhadap anggota sebagai saksi korban dan saksi lainnya. Penyidik Polri selain sebagai pengemban tugas dan fungsi Kepolisian juga memiliki kewenangan dalam penyidikan dan penegakan hukum terhadap anggota atau oknum yang melakukan tindak pidana. Selain dari hal tersebut diatas, aparat penyidik wajib memperhatikan dan menyelesaikan dengan sebaik-baiknya laporan
\end{abstract}


dan atau pengaduan dari masyarakat sesuai tugas dan fungsinya selaku penyidik. Penyidikan terhadap anggota Kepolisian Negara Republik Indonesia yang melakukan tindak pidana, dilakukan oleh penyidik sebagaimana diatur dalam hukum acara pidana yang berlaku di lingkungan peradilan umum, yang dipertegas dalam Pasal 2 Peraturan Pemerintah Republik Indonesia Nomor 3 tahun 2003 tentang Pelaksanaan Teknis Institusional Peradilan Umum bagi anggota Kepolisian. Negara Republik Indonesia. Pemeriksaan terhadap anggota Polri dilaksanakan sesuai jenjang kepangkatan yakni sesuai ketentuan Pasal 5 Peraturan Pemerintah Nomor 3 Tahun 2003 tentang pelaksanaan teknis institusional peradilan umum bagi anggota Polri dimana pemeriksaan terhadap anggota Polri dalam rangka penyidikan dilakukan dengan memperhatikan kepangkatan. Pemeriksaan dalam rangka penyidikan dilakukan sesuai dengan Pasal 5 Peraturan Pemerintah Nomor 3 Tahun 2003 berdasarkan kepangkatannya.

Kata Kunci : Kode Etik, Pelanggaran, Polisi, Tindak Pidana.

\section{PENDAHULUAN}

Kepolisian adalah salah satu aparat penegak hukum yang selalu berada di garis terdepan dalam mengayomi, melayani dan melindungi masyarakat. Dalam menjalankan tugasnya tidaklah mudah dalam menghadapi masalah-masalah yang berada di dalam masyarakat, Kepolisian kadang kala mendapatkan respon yang kurang bersahabat dari masyarakat ketika melayani masyarakat. Oleh karena itu untuk memahami eksistensi Kepolisian tidak dapat dilepaskan dengan fungsi dan organ atau lembaga Kepolisian. Pasal 2 Undang-undang Republik Indonesia (selanjutnya disingkat UURI) No. 2 Tahun 2002 No. 2 tahun 2002 tentang Kepolisian Negara Republik Indonesia (selanjutnya disingkat POLRI) berbunyi bahwa : Fungsi kepolisian adalah salah satu fungsi pemerintahan negara di bidang pemeliharaan keamanan dan ketertiban masyarakat, penegakan hukum, perlindungan, pengayoman dan pelayanan kepada masyarakat, serta tidak dapat dilepaskan dari konsep pemikiran tentang adanya perlindungi hukum bagi masyarakat. Dalam perspektif fungsi maupun lembaga, Kepolisian memiliki tanggung jawab untuk melindungi masyarakat dari segala bentuk ancaman kejahatan dan gangguan yang dapat menimbulkan rasa tidak aman, tidak tertib dan tidak tentram. Pada pengertian di atas, dapat diketahui bahwa POLRI sebagai salah satu fungsi pemerintahan negara yang substansinya memuat hal di bidang pemeliharaan keamanan dan ketertiban masyarakat, penegakan hukum, pelindung, pengayom dan pelayanan kepada masyarakat yang merupakan sesuatu yang sakral karena bersifat bathin dan kekal yang berdasarkan hak asasi manusia dan Ketuhanan Yang Maha Esa. Selain itu pernyataan tentang tujuan POLRI sangat penting artinya bagi pembentukan jati diri POLRI, karena tujuan akan memberikan batasasan dan arah tentang apa yang harus dicapai melalui 
penyelenggaran fungsi POLRI dalam keseluruhan perjuangan bangsa untuk mencapai tujuan nasional. Kejelasan tujuan POLRI akan memberikan pula kejelasan visi dan misi yang diemban POLRI sehingga pada gilirannya akan merupakan pedoman bagi penentuan metode pelaksanaan tugasnya secara tepat.

Dalam menjalankan fungsi sebagai aparat penegak hukum POLRI wajib memahami asas-asas hukum yang digunakan sebagai bahan pertimbangan dalam pelaksanaan tugas, yaitu sebagai berikut:

a. Asas legalitas, dalam melaksanakan tugasnya sebagai penegak hukum wajib tunduk pada hukum.

b. Asas kewajiban, merupakan kewajiban polisi dalam menangani permasalahan dalam masyarakat yang bersifat diskresi, karena belum diatur dalam hukum.

c. Asas partisipasi, dalam rangka mengamankan lingkungan masyarakat polisi mengkoordinasikan pengamanan Swakarsa untuk mewujudkan ketaatan hukum dikalangan masyarakat.

d. Asas preventif, selalu mengedepankan tindakan pencegahan dari pada penindakan (represif) kepada masyarakat.

e. Asas subsidaritas, melakukan tugas instansi lain agar tidak menimbulkan permasalahan yang lebih besar sebelum ditangani oleh instansi yang membidangi.

UURI No. 2 Tahun 2002 Tentang POLRI diatur dengan lengkap dan runtut mengenai tugas dan wewenang POLRI, namun ada saja penyimpanganpenyimpangan yang dilakukan oleh POLRI tersebut dalam menjalankan tugasnya. Penyimpangan yang dilakukan oleh POLRI merupakan suatu pelanggaran kode etik yang jarang didengar namun banyak terjadi pada anggota POLRI yang berada di kota - kota tertentu yang memiliki jumlah penduduk padat. Pelanggaran Kode Etik ini merupakan hal yang kurang diminati untuk diperbincangkan karena hal ini merupakan hal yang berkaitan dengan urusan pribadi orang yang bersangkutan, selain itu, juga menimbulkan rasa malu pada korban/pelaku dan keluarga korban/pelaku maupun institusi.

Warga masyarakat Indonesia juga banyak tidak mengetahui adanya jenis pelanggaran ini, dikarenakan kurangnya sosialisasi mengenai jenis pelanggaran ini. Apabila masyarakat melihat suatu penyimpangan atau kesalahan yang dilakukan oleh oknum POLRI dalam keadaan tertentu masyarakat jarang melaporkan bahkan tidak mau melaporkan penyimpangan tersebut karena malas berurusan dengan pihak POLRI, padahal keadaan tersebut harus dilaporkan ke Sentra Pelayanan Kepolisian (selanjutnya disingkat SPK) pada kantor POLRI terdekat sehingga dapat diproses menurut hukum acara di lingkungan peradilan 
umum. Penyimpangan perilaku oknum POLRI tersebut merupakan pelanggaran terhadap peraturan disiplin anggota POLRI yang diatur dalam UURI Nomor 2 Tahun 2002 Tentang POLRI. Upaya penegakan Kode Etik Profesi POLRI sangat dibutuhkan untuk terwujudnya pelaksanaan tugas yang dibebankan pada profesionalisme POLRI.

Ketidak profesionalisme akan sangat berdampak dalam hal penegakan hukum atau pengungkapan kejahatan yang terjadi di masyarakat. Seringnya diberitakan di berbagai media massa mengenai tindakan penyimpangan yang dilakukan oleh anggota POLRI, misalnya banyaknya kasus penyalah gunaan senjata api oleh anggota POLRI, adanya anggota POLRI yang terlibat dalam tindak pidana, tindakan sewenang-wenang anggota POLRI, termasuk dalam hal ini kasus pengrusakan fasilitas kampus, penganiayaan mahasisiwa Universitas Makassar Negeri (selanjutnya disingkat UNM) dan penganiayaan jurnalis oleh beberapa anggota polisi pada saat pengamanan aksi demo mahasiswa yang menolak rencana kenaikan Bahan Bakar Minyak ( selanjutnya disingkat BBM) di Makassar pada 13 November 2014 menjadikan keprihatinan sendiri bagi masyarakat terkait dalam pelaksanaan tugas pokok POLRI yang disebutkan dalam Pasal 4 UURI Nomor 2 Tahun 2002 Tentang POLRI yang berbunyi : Menjaga keamanan dan ketertiban masyarakat, tertib dan tegaknya hukum, terselenggaranya perlindungan, pengayoman dan pelayanan kepada masyarakat, serta terbinanya ketentraman masyarakat dengan menjunjung tinggi hak asasi manusia. Sulit rasanya memishkan keeratan hubungan antara mayarakat dengan POLRI. Tidak ada masyarakat tanpa POLRI (ubi societas ubi politie).

POLRI merupakan sebuah institusi hukum yang cukup tua keberadannya, setua usia kehidupan bermasyarakat dalam sejarah manusia. Seperti kita ketahui, POLRI (mulai dalam bentuknya yang amat sederhana sampai POLRI modern) dimanapun di dunia ini mempunyai dua peran sekaligus.

\section{METODE PENELITIAN}

Di dalam pelaksanaan penelitian ini, data yang diperoleh oleh penulis akan dianalisis dengan menggunakan metode Analisis kuantitatif, yaitu data yang diperoleh dibuat dalam bentuk tabulasi dan diberi analisis deskriptif persentase.

\section{PEMBAHASAN}

\section{A. Proses pemeriksaan terhadap pelanggaran kode etik profesi POLRI} terhadap anggota POLRI yang melakukan tindak pidana.

Tugas dan Fungsi PPNS Bea dan Cukai Pejabat Bea dan Cukai adalah pegawai Direktorat Jenderal Bea dan Cukai yang ditunjuk dalam jabatan 
tertentu untuk melaksanakan tugas tertentu berdasarkan Undang-Undang Nomor 17 Tahun 2006 tentang Kepabeanan dan Undang-Undang Nomor 39 Tahun 2007 tentang Cukai.

Pelanggaran hukum dan penyalah gunaan kewenangan merupakan isu yang sangat relevan dengan kondisi sosial saat ini. Hal ini masih diwarnai oleh pengalaman masa lalu akan adanya pengabaian dan ketidak hormatan atas hukum, yang sekaligus mengakibatkan ketidak percayaan terhadap hukum yang masih terjadi hingga kini. Perubahan sosial yang begitu cepat dan runtuhnya wibawa hukum memberikan pengaruh untuk mendorong pada perilaku . Disisi lain penyimpangan yang dilakukan oleh anggota POLRI, baik yang dilakukan ketika menjalankan tugas maupun diluar tugasnya yang selanjutnya berkembang menjadi opini publik, semakin memperburuk citra POLRI.

Salah satu tolak ukur keberhasilan kinerja POLRI saat ini adalah tegaknya supremasi hukum, keluar maupun ke dalam institusi POLRI yang merupakan komitmen yang dideklarasikan dan diamanatkan kepada pemerintah oleh para pencetus reformasi. Dalam penegakan supremasi hukum, langkah terbaik adalah penegakan yang dimulai dari aparat penegak hukum dalam artian POLRI. Karena dalam pelaksanaan tugas maupun diluar tugas tidak jarang ditemui anggota POLRI melakukan tindak pidana. Permasalahannya adalah, ketika anggota POLRI terlibat dalam suatu tindak pidana, kemudian penyidiknya dari fungsi Reserse POLRI.

Hal ini sangat mempengaruhi obyektifitas penegakannya, karena disinyalir muncul rasa tidak tega dalam keseriusan melakukan penyidikan. Demikian juga dengan Atasan Yang Berhak Menghukum (Ankum) yang dirasakan kurang obyektif dalam melakukan penindakan terhadap anggotanya bahkan membebaskan tersangka dari jeratan hukuman. Kode etik profesi merupakan suatu pegangan bagi setiap anggota profesi yang berfungsi sebagai sarana kontrol sosial. Demikian, kalau dikatakan bahwa etika profesi merupakan pegangan bagi anggota yang tergabung dalam profesi tersebut, maka dapat pula dikatakan bahwa terdapat hubungan yang sistematis antara etika dengan profesi hukum.

Institusi Kepolisian dalam menjalankan tugasnya telah dibekali oleh sebuah pedoman yang sangat baik. Namun suatu hal yang tidak dapat dipungkiri, masih banyak anggota kepolisian yang menjalankan tugasnya justru tidak mematuhi pada pedoman tersebut, inilah persoalannya. Kenyataannya masih banyak pula anggota Polri yang melanggar Kode Etik Profesi Kepolisian. Contohnya saja anggota POLRI yang berada di wilayah 
Polda Sulsel-bar masih ada yang terlibat suatu tindakan pidana dan ada pula yang meninggalkan tugas selama 30 hari kerja berturut- turut.

Proses dari penangan Polisi yang melanggar kode etik profesi Kepolisian dalam melakukan pelanggaran tindak pidana adalah sebagai berikut:

1) Anggota POLRI yang melakukan tindak pidana diadukan/dilaporkan oleh masyarakat, anggota POLRI lain atau sumber lain yang dapat dipertanggung jawabkan.

2) Setelah adanya laporan tersebut, Provos pada setiap jenjang organisasi Polri, seperti Divisi Profesi dan Pengamanan (Divpropam) pada tingkat Mabes POLRI melakukan pemeriksaan pendahuluan dan apabila dari hasil pemeriksaan pendahuluan yang dirasa belum lengkap oleh Urusan Provos maka kewenangan penyelidikan diambil alih oleh Urusan Paminal.

3) Proses penyelidikannya tidak hanya Urusan Paminal yang melakukan penyelidikan, tetapi juga Unit Reskrim.

4) Selanjutnya Urusan Paminal melaporkan kepada Urusan Provos untuk kemudian dilanjutkan pada proses penyidikan terhadap adanya pelanggaran kode etik dan Unit Reskrim melanjutkan pada proses penyidikan terhadap tindak pidana yang telah terjadi sesuai dengan yang telah diatur dalam KUHAP.

5) Setelah penyidikan yang dilakukan oleh Provos dan Reskrim telah terbukti kebenarannya bahwa telah terjadi pelanggaran Kode Etik Profesi Kepolisian, maka berkas perkara tersebut dikirimkan kepada Ankum dan mengusulkan diadakannya sidang Komisi Kode Etik Polri (KKEP).

6) Sidang yang dilakukan untuk menangani suatu tindakan pidana yang dilakukan oleh anggota POLRI, yaitu sidang peradilan umum atau di pengadilan negeri terlebih dahulu sampai mendapatkan putusan yang berkekuatan hukum tetap baru kemudian dilanjutkan sidang KKEP.

Berdasarkan tahapan-tahapan yang dilakukan diatas berikut adalah penjelasannya secara lebih rinci, Bahwa dasar penyidikan terhadap Anggota Polri yang disangka melakukan tindak pidana adalah adanya laporan atau pengaduan dari masyarakat. Laporan atau pengaduan tersebut disampaikan melalui Kepala Seksi Pelayanan Pengaduan Bidang Profesi dan Pengamanan (Kasi Yanduan Bid Propam), selanjutnya Kabid Propam mendisposisikan kepada Kepala Sub Bagian Provos (Kasubbid Provos) melalui Kepala Unit Penyidik (Kanit Idik) untuk melakukan pemanggilan dan pemeriksaan terhadap anggota dimaksud berikut saksi korban dan saksi-saksi lainnya. Penyidik Polri selain sebagai pengemban tugas dan fungsi Kepolisian juga memiliki kewenangan dalam penyidikan dan penegakan hukum terhadap 
anggota atau oknum yang melakukan tindak pidana. Selain dari hal tersebut diatas, aparat penyidik wajib memperhatikan dan menyelesaikan dengan sebaik-baiknya laporan dan atau pengaduan dari masyarakat sesuai tugas dan fungsinya selaku penyidik.

Penyidikan terhadap anggota Kepolisian Negara Republik Indonesia yang melakukan tindak pidana, dilakukan oleh penyidik sebagaimana diatur dalam hukum acara pidana yang berlaku di lingkungan peradilan umum, yang dipertegas dalam Pasal 2 Peraturan Pemerintah Republik Indonesia Nomor 3 tahun 2003 tentang Pelaksanaan Teknis Institusional Peradilan Umum bagi anggota Kepolisian. Negara Republik Indonesia. Pemeriksaan terhadap anggota POLRI dilaksanakan sesuai jenjang kepangkatan yakni sesuai ketentuan Pasal 5 Peraturan Pemerintah Nomor 3 Tahun 2003 tentang pelaksanaan teknis institusional peradilan umum bagi anggota POLRI dimana pemeriksaan terhadap anggota POLRI dalam rangka penyidikan dilakukan dengan memperhatikan kepangkatan. Pemeriksaan dalam rangka penyidikan dilakukan sesuai dengan Pasal 5 PP No 3 Tahun 2003 berdasarkan kepangkatannya, yakni :

a. Tamtama diperiksa oleh anggota Kepolisian Negara yang berpangkat serendah- rendahnya Bintara.

b. Bintara diperiksa oleh anggota Polisi serendah-rendahnya berpangkat Bintara.

c. Perwira Pertama, diperiksa oleh anggota Polisi yang berpangkat serendah - rendahnya Bintara

d. Perwira Menengah diperiksa oleh anggoata yang berpangkat serendah rendahnya Perwira Pertama

e. Perwira Tinggi diperiksa serendah-rendahnya oleh anggota yang berpangkat Perwira Menengah.

B. Faktor Faktor yang menghambat PPNS Bea dan Cukai dalam Menangani Tindak Pidana Penyelundupan MMEA

Dalam melakukan penyidikan, penyidik tidak terlepas dari faktor-faktor penghambat dalam melakukan penyelidikan. Berkaitan dengan penyidikan terhadap tindak pidana, yang merupakan bagian dari penegakan hukum pidana, menurut Soerjono Soekanto25 tidak terlepas dari faktorfaktor yang menghambat sebagai berikut:

1. Faktor perundang-undangan (substansi hukum).

Bahwa semakin baik suatu peraturan hukum akan semakin memungkinkan penegakannya, sebalikya semakin tidak baik suatu peraturan hukum akan semakin sukarlah menegakkannya. Secara umum 
bahwa peraturan hukum yang baik adalah peraturan hukum yang berlaku secara yuridis, sosiologis dan filosofi.

2. Faktor penegak hukum Bahwa faktor penegak hukum ini menentukan proses penegakan hukum yaitu pihak-pihak yang menerapkan hukum tersebut. Adapun pihak-pihak ini yang langsung terkait dalam proses fungsionalisasi huktim pidana terhadap perbuatan yang merusak obyek dan daya tarik wisata.

3. Faktor Prasana atau Fasilitas

Penegakan hukum akan berlangsung dengan baik apabila didukung dengan sarana atau fasilitas yang cukup. Sarana atau fasilitas ini digunakan untuk mencapai tujuan, yaitu tercapainya masyarakat yang tertib dan taat hukum.

4. Faktor kesadaran hukum Merupakan bagian terpenting dari masyarakat yang menetukan penegakan hukum dan kesadaran hukum merupakan pandangan yang hidup dalam masyarakat tentang apa hukum itu, sedangkan kesadaran hukum masyarakat yang memungkinkan dilaksanakannya penegakan hukum itu. Kemudian jika dari hasil pemeriksaan Kanit Idik atau anggota Idik, mengarah pada tindak pidana, maka Kabid Propam setelah meminta saran dan pendapat hukum pada Bid Binkum melimpahkan perkara tersebut kepada Dit Reskrim (untuk tingkat Mapolda) atau Kasi Propam melimpahkan perkara ke Satuan Reskrim (untuk kewilayahan) dengan tembusan Ankum di mana anggota tersebut ditugaskan. Selanjutnya dalam Pasal 10 ayat (1), (2) dan ayat (3) PP No 3 Tahun 2003 tentang Pelaksanaan Teknis Institusional Peradilan Umum Bagi Anggota POLRI dijelaskan bahwa :

a) Anggota POLRI yang dijadikan tersangka / terdakwa dapat diberhentikan sementara dari jabatan dinas Kepolisian Negara Republik Indonesia, sejak dilakukan proses penyidikan sampai adanya putusan pengadilan yang mempunyai kekuatan hukum tetap.

b) Pemberhentian sementara dari jabatan dinas POLRI dapat dilakukan secara langsung.

c) Ketentuan tentang tata cara pelaksanaan pemberhentian sementara sebagaimana di maksud dalam ayat (2) diatur dengan Keputusan Kapolri. Pemberhentian sementara dari dinas POLRI sebagaimana dimaksud Pasal 10 di atas, bertujuan untuk memudahkan proses penyidikan, dalam arti bahwa status anggota POLRI ketika dilakukan penyidikan dikembalikan sebagai anggota masyarakat, sehingga proses penyidikan dapat berjalan sebagaimana yang diharapkan. Namun yang 
perlu dipahami adalah bahwa Pasal 10 ayat (1) tersebut menggunakan kata dapat, yang menurut Kamus Besar Bahasa Indonesia, makna dapat diartikan bisa, mampu, sanggup, boleh, mungkin. Dengan demikian kata "dapat" bisa diartikan "dilakukan pemberhentian sementara dari dinas Kepolisian dan bisa tidak dilaksanakan pemberhentian sementara dari dinas Kepolisian", karena kata "dapat" tidak mengandung suatu kewajiban atau perintah. Pengertian ini sangat memungkinkan digunakan oleh pejabat yang berwenang terhadap anggota POLRI yang dalam proses penyidikan, tidak dilakukan pemberhentian sementara.

\section{PENUTUP}

\section{A. Kesimpulan}

Berdasarkan pembahasan diatas maka, disimpulkan sebagai berikut :

1) Jenis pelanggaran pidana yang dilakukan oleh anggota kepolisian bisa berupa: pembunuhan, pemukulan atau tindak kekerasan, penganiayaan, pencurian, penipuan, pemerasan, terorisme, pencucian uang, korupsi, Pencemaran nama baik, dan hal lalin sebagaimana tertera dalam Kitab Undang-Undang Hukum Pidana. Dalam pasal 11 Peraturan Pemerintah No. 1 Tahun 2003 Tentang Pemberhentian Anggota Kepolisian Negara Republik Indonesia , dijelaskan bahwa jenis tindakan yang bisa menyebabkan seorang anggota kepolisian negara dapat diberhentikan tidak dengan hormat adalah melakukan tindak pidana, melakukan pelanggaran dan meninggalkan tugas atau hal lain.

2) Proses dari penanganan Polisi yang melanggar kode etik profesi Kepolisian dalam melakukan pelanggaran tindak pidana adalah pada dasarnya dilakukan sesuai dengan ketentuan Kitab Undang- Undang Hukum Acara Pidana (KUHAP), dengan mengingat, memperhatikan dan berpedoman kepada ketentuan-ketentuan yang mengatur secara khusus bagi tersangka anggota POLRI sebagaimana diuraikan di atas.

\section{B.Saran -Saran}

1) Bagi pihak Kepolisian, agar suatu peraturan Kode Etik Profesi POLRI dapat diterapkan dengan baik, maka sebaiknya POLRI lebih meningkatkan pengawasan kinerja terhadap para anggotanya dengan cara, seperti melakukan pembinaan sesuai dengan profesi, menekankan nilai moral dalam diri setiap individu supaya berperilaku sesuai dengan kode etik profesi yang melekat pada diri setiap anggota POLRI serta mengamalkan dasar dari kepolisian agar tidak terjadi pelanggaran kode etik profesi lagi. 
2) Bagi Masyarakat Diharapkan masyarakat lebih dapat memahami bagaimana mekanisme penanganan anggota Polri yang melakukan pelanggaran tindak pidana maupun disiplin kerja, sehingga masyarakat mengetahui bahwa aparat penegak hukum dapat ditindak secara tegas dan jauh lebih berat hukumannya dari masyarakat umum apabila melakukan suatu pelanggaran. 


\section{DAFTAR PUSTAKA}

A. Buku

Andi Hamzah. Sistem Pidana dan Pemidanaan Indonesia dari Retribusi ke Reformasi. Bandung: Pradnya Paramita, 2011.

Herbert L. Packer. The Limits of Criminal Sanction, 1968.

Miranda Davies (Ed.). Women and violence : Realities and Responses World Wide, $2^{\text {nd }} e d$. London and New York: Zed books Ltd, 1997.

Michel Victory (Ed.). For better or worse : Family Violence in Australia. Victoria: CIS Publisher, 1993.

Moerti Hadiati Soeroso. Kekerasan Dalam Rumah Tangga Dalam Perspektif Yuridis- Viktimologis. Jakarta: Sinar Grafika, 2010.

Moeljatrio. Azas-Azas Hukum Pidana. Yogyakarta: Gajah Mada University Press, 2012.

Momo Kelana. Memahami Undang-Undang Kepolisian: Latar Belakang dan Komentar Pasal demi Pasal. Jakarta: PTIK Press, 2002.

M. Manullang. Dasar-Dasar Management. Jakarta: Ghalia Indonesia, 2012.

P.A.F, Lamintang. Hukum Panitensier Indonesia. Bandung: Armico, 2010.

Roni Hanitijo Soemitro. Metodologi Penelitian Hukum dan Jurimetri. Jakarta: Ghalia Indonesia, 2011.

R. Abdussalam. Hukum Pidana Prospek Indonesia dalam Mewujudkan Rasa Keadilan Masyarakat. Jakarta: Restu Agung, 2006.

Soerjono Soekanto. Pengantar Penelitian Hukum. Jakarta: UI Press, 2010.

Sugiyono. Memahami Penelitian Kualitatif. Bandung: Alfabeta, 2010.

B. Peraturan Perundang-Undangan

Undang-undang Nomor 2 Tahun 2002 Tentang Kepolisian Negara Republik Indonesia Kitab Undang-Undang Hukum Acara Pidana (KUHAP)

Peraturan Pemerintah Nomor 14 Tahun 2011 Tentang Kode Etik Profesi Kepolisian Republik Indonesia

Peraturan Pemerintah Nomor 3 Tahun 2003 Tentang Pelaksanaan Teknis Institusional Peradilan Umum Bagi Anggota POLRI

Peraturan Pemerintah Nomor 2 Tahun 2003 tentang Peraturan Disiplin Anggota POLRI 